\title{
Martina OLIVERO
}

\section{The Politics of Images. Critical Approach and Documentary Experimentations in Harun Farocki and Andrei Ujică Videogramme einer Revolution (Videograms of a Revolution, Germany, 1992)}

\begin{abstract}
The aim of the article is to show which status images assume in the aesthetics of Harun Farocki and Andrei Ujică, both coming from Eastern cultures but long-standing German residents. As a fact, Central Europe film industry could offer more opportunities, since Eastern Europe's recent history has been suffering from the protracting influence of the Soviet Union. In particular, the focus here is on the late XX century events that twisted Romania and occupied an important place in the cinematography of both authors. Videograms of a revolution (Germany, 1992) is undoubtedly their masterpiece. What emerges from this film is the dialectical role that images play in relation with history and political power in the context of the ' 89 revolution. Since their function is not only commemorative but ontological, Farocki and Ujică use a critical approach, which belongs to the German philosophical and sociological culture, started from Kant and then pursued by the Institute for Social Research of Horkheimer and Adorno, to study how images have been doubly used for and against the communist propaganda. By experimenting with a new documentary form, Farocki and Ujică intend to question the responsibility of the camera in influencing the course of history.
\end{abstract}

Keywords: Romanian cinema, Critical theory, 1989 Romanian revolution, media theory, status of images, documentary, Eastern-Central Europe.

\section{Martina OLIVERO}

Institute Acte - CNRS

University of Paris 1, Sorbonne

Email: Martina.Olivero@univ-paris1.fr

EKPHRASIS, 2/2017

Transnational Cinema Dialogues

pp. 29-46

DOI:10.24193/ekphrasis.18.3

Published First Online: 2017/12/30

\section{Introduction}

Speaking of transnational cinema dialogues, Harun Farocki is an excellent example of how the attention paid by the Central Europe's cinematographic tradition to major and minor events in Eastern Europe allows, on one side, to convey a precise aesthetics and, on the other, to raise public awareness of a history often dominated by Eurocentrism 
and a brutally and mainly Western ideological, political, artistic and social influence. So, from the meeting between the curiosity and the mastery of the German director (born in 1944 to a German mother and an Indian father in the Nazi Protectorate of Bohemia and Moravia) and the talent of Andrei Ujică (born in Romania but living in Germany since 1981), a masterpiece such as Videograms of a revolution (1992), considered by Les cahiers du cinéma as one of the hundred most subversive films of all time (62), was able to see the light. With this experimental documentary, the two directors produced a major cinematographic example of the relationship between media and political power at the end of the cold war. Farocki and Ujică create a new aesthetic experience avoiding traditional forms of representation. Combining archival footage, historical films, institutional and amateur videos with their dramatic and non-fictional work, a new (non-)narrative form is born and examines the way we perceive and understand images. What emerges from the collaboration and the production of these two authors, beyond a political attention to what was happening « on the fringes » of Europe, is a new status of the image. There are no longer images that record history, but images that have taken power over history itself.

\section{Ujică and the East-European identity}

To be precise, Videograms a revolution is not a Romanian film but a German film about Romania that would not have been possible without the contribution of Andrei Ujică. Born and schooled in Timişoara, Ujică emigrated to Germany in the 80s and, in 1991, co-directed this film with Farocki. The movie is entirely built through a montage of television footage and amateur videos of the 1989 Romanian revolution, by this constituting an example of a visual historiography which is able to show several points of view, coming from different sources, on the same historical subject. On this issue, Dominique Nasta, author of Contemporary Romanian Cinema (2013), notes how the presentation of several images on the same fact not only shows a variety of viewpoints but eventually investigate the reality of the event itself (Nasta 83). In other words, it is the very status of the image that, through this procedure of métis and plural montage, is questioned. The two directors, by a unique combination of official and amateur images, show how the major challenge of Romania in the early nineties is to establish a truth beyond any censorship or rewriting operated by the regime. According to Nasta (83), this challenge was raised only a decade or so later by the new generation of Romanian filmmakers who, through a minimalist aesthetics and a dark humour, are working in particular on the battles of young people for total freedom of press and expression. Thus, Videograms of a revolution is not just a German film about Romania, but an experimental and non-narrative documentary that fully belongs to the Romanian and Eastern European film tradition. Together with Bucureşti, Piaţa Universităţii (Bucharest, University Square, Romania, 1991) by Stere Gulea, Sorin Ilieşiu and Vivi Drăgan Vasile, they represent the two most important documentaries about the Romanian revolution. 

and Andrei Ujică Videogramme einer Revolution (Videograms of a Revolution, Germany, 1992)

Of course, the two films had a very different genesis and distribution. Bucureşti, Piaţa Universității holds full Romanian origins and was the first movie of Cinema Studio funded by the Ministry of Culture in the immediate post-revolutionary period (Nasta 81). Pintilie, the major representative of this new generation of Romanian filmmakers, director of the Studio, felt the moral obligation to produce a movie about the events that forever changed the geopolitics of Romania and the Balkans. The recorded events start from April 1990, when thousands of people, mostly students, gathered in University Square in Bucharest to demand the resignation of Ion Iliescu, who had been appointed as head of the interim government after the overthrow of Ceaușescu, were attacked and beaten by the political police. Founder of the National Salvation Front (Frontul Salvării Naţionale, FSN), born from the dissolution of the Communist Party, Iliescu was president until the parliamentary elections of 20 May 1990. But public opinion, after his clear victory of the elections with $85 \%$ of the votes, realised that the FSN had taken control of all the structures, the goods and the resources of the State and that it was preparing to reimpose a communist dictatorship. With the large place reserved to him by the Romanian television, Iliescu called his opposition a "hooliganade" (from golaniade in Romanian, in turn from golan, thug) and prepares the third mineriade (mineriadă). Beacuse of this, in order to create an anti-protest movement, the president appealed to the miners of the Jiu region to intervene against the movement of intellectuals and students he presented as anti-communist and favourable to the investments of foreign capitalists. Nearly ten thousand minors, helped by former members of the brutal Securitate (the Romanian secret services officially abolished in December 1989) and the political police of the fallen dictatorship were seen to beat and rape men, women and children, not only around the University Square but even in their apartments, while the seats of political parties and hostile newspapers were ransacked. The directors of Piaţa Universității then choose to show, according to a close documentary approach as that of Farocki-Ujică, amateur videos directly filmed from the site, interviews given by the principal leaders of the protest movement and the official images shown by the state television. The objective of the film was, trough the graphicness and the disparity of the images, to appeal to the moral conscience of every Romanian citizen.

This choice which consists in awakening the collective memory using different sources around the same event, was then adopted by other contemporary Romanian directors. An example is provided by Corneliu Porumboiu (Vaslui, 1975) who has adapted it to a minimalist aesthetics balanced between irony and melancholy. But it is also the case of the film How I Spent the End of the World (Cum mi-am petrecut sfârşitul lumii, 2006) directed by Cătălin Mitulescu (Bucharest, 1972) based on a script written with Andreea Vălean (Bucharest, 1972). The film, a wholly Romanian history, internationally funded and fully conscious of the importance of an international audience, in its closing stage transfers the power of the image to the television medium, where archival footage and fiction elements are blended to represent the fall of dic- 
tator Ceaușescu. To be sure, the question of funding is not trivial in a country where artistic, literary and film production was strongly controlled during the communist regime and inevitably began to decline from the 90s, until it was reduced to zero in 2000, the dark year of Romanian cinema, when no local film was released (Uricaru 427). Still according to Uricaru, Mitulescu is part of the first generation of young directors also called Romanian New Wave or New Romanian Cinema (which include Puiu, Mungiu, Porumboiu, Mitulescu and Muntean) who helped Romanian cinema to break this deadlock during the first decade of the XXI century (Uricaru 428). This has resulted in an unprecedented international consecration: at Cannes Film Festival the prize Un Certain Regard was awarded to Death of Dante Lazarescu (Moartea domnului Lăzărescu, 2005) by Cristi Puiu and to California dreamin' (California dreaming (nesfirşit), 2007) by Cristian Nemescu; the prize La caméra d'or assigned to 12:08 East of Bucharest (A fost sau n-a fost, 2006) by Corneliu Porumboiu and the Palme d'Or recorded to short films Traffic (2004) by Cătălin Mitulescu, Megatron (2008) by Marian Crişan and to feature film 4 Months, 3 Weeks and 2 Days (4 luni, 3 săptămîni și două zile, 2007) directed by Christian Mungiu.

In turn, The way I spent the end of the world (Romania, 2006) was consecrated as best screenplay at the Sundance Film Festival, which allowed him to obtain funding from Eurimages, Canal + and Acht Frankfurt, to collaborate with the French film production company Les films Pélleas and be distributed by Pyramides Distribution. As a result, we talk about a Franco-Romanian co-production produced by Strada Film and Pélleas. The film, four years before the movie made by Ujică on Romania from the communist era, Autobiography of Nicolae Ceaușescu (2010), is a fiction nourished by historical elements, a story built in the opposite way than the Autobiography which, on the contrary, stages the narration as if it were a fictional novel. A Ceaușescu in his later years appears at the beginning of the film by Mitulescu to award the symbolic prize of a cheese wheel to young schoolboy Lalalilu (Timotei Duma), prize that the dictator suddenly decides to take back because of the early age of the winner. Thus, a series of adventures begins, common to both symbolic periods of the life of Matei brothers, childhood for Lalalilu and adolescence for Eva, the eldest. At the same time, because of the historical era that Romania traverses between the late eighties and early ninety years, brother and sister, with all the people that accompany them, are faced to the exceptional situations of the communist regime, from the official portraits of Ceaușescu hung on every classroom wall, to school propaganda and the repressions of the Securitate, summary arrests, economic restrictions, censorship. Everything is told through the innocent but perfectly lucid eyes of Lalalilu who plays the role of a child but is in fact already an adult, the only one who manages to lead, by a lucky succession of events, a concrete and successful challenge to the regime. Concentrated on a project as chimerical as it was driven by real determination, namely " to kill Ceaușescu », Lalalilu, from the University square, assists live to his surrender. This event, to which he seems to have bravely contributed, then allows his beloved sis- 
ter Eva to finally embark on the boat that would have bring her in Europe, where her dreams could come true. Thus, as in the film by Ujică, the images transmitted on TV of the last speech of Ceaușescu on the main square in Bucharest are from original videos shot by the regime's official channel (Image 1). For all the Romanian people and Lalalilu, it represents the fall of a regime that lasted twenty-five years and at cries of « we are free! » the end of a world is truly accomplished.

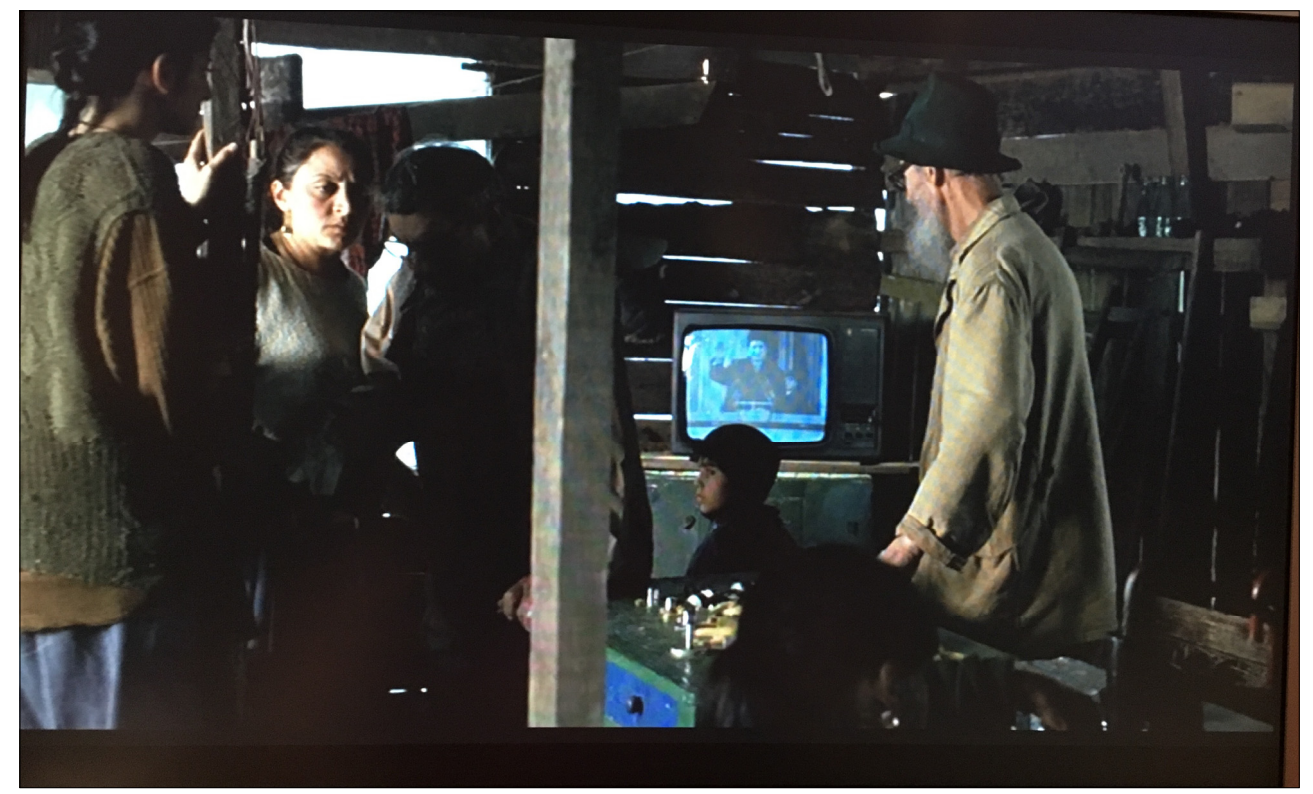

Image 1. The way I spent the end of the world

(Cum mi-am petrecut sfârşitul lumii, Cătălin Mitulescu, France-Romania, 2006, min. 1:27)

In the film Out of the Present (Germany, 1995), Ujică decides to use the same technique of overlaying images, through the use of two different sources. Footage from more than 280 hours of recordings shot from the Mir orbital station during the Ozon mission is interspersed with amateur videos of the violent confrontations that followed the Moscow putsch in August 1991. On May 18 1991, astronauts from the Soyuz TM-12 mission, Helen Sharman (United Kingdom) and Sergei Krivalev (USSR Russia) commanded by Anatoly Artsebarski (USSR - Ukraine) are launched to the Mir station where they carry out their research in the context of the Mir EO-9 expedition. The cinematographic work by Ujică follows Major Artsebarski's 144 days in space. Artsebarski, returned to earth on October 10, 1991, while Krivalev, who had landed only ten months later, went back only on March 25, 1992. The reason of this unexpected prolongation was the extreme political instability of the months that saw the coup of conservatives of the Soviet Union Communist Party against the reformism of President Gorbachev, the rise of the figure of Boris Yeltsin, the collapse of the Soviet Union's institutions and the birth of the Russian Federation on 25 December 1991. Krivalev, 
" out of the present ", is known to be the only cosmonaut to have carried out a mission for a formally non-existent country and to have been a witness of its dissolution from orbit. Asked about his feelings about the fact that, for example, his hometown is no longer called Leningrad but Saint Petersburg, the astronaut remains vague, mentioning the wonderful images he was able to observe and record from up there during his last months in space. Through this particular device of using two sets of images of very different nature, Ujică emphasises the violence of the contrast between the weightlessness and the lightness of terrestrial landscapes, the slow movements of the station which floats around the earth, like in a waltz, and the cries, the violence, the imposing dimensions of the tanks that pass through Moscow alongside the passersby. Ninety-two minutes, the duration of the documentary, is the turnaround time of the station around the earth and the choice of the director may want to underline the distance between a time, that of the orbit, and space, that of the earth, between fiction and history, infinite elevation and earthly existence, astronomy and politics, alienation and protest, galactic universe and historical events.

Twenty years after the co-direction of Videograms and fifteen years after Out of the present, Ujică presents another extremely significant work showing that Romanian and Eastern European cinema is not dead but still able to renew itself non-stop. Autobiography of Nicolae Ceaușescu (Autobiography of Nicolae Ceaușescu, Romania, 2010) is a three-hour feature film directed on previously existing material that opens in a new kind of autobiographical narrative or bio-pic. Indeed, Ujică's goal here is to revive, at twenty years after the assassination of the Romanian dictator, more than a thousand hours of television archive material, mostly propagandist, and unpublished videos that trace his ascension, life and dramatic fall. To do this, the director decides to reconstruct the succession of historical events as if they were part of the scenario of a fictional film. Thirty years of Romanian and world history (1965-1989) are presented here in the style of an exciting novel (Jeong - Szaniawski 166). Ujică then decides to mix chronological parameters, starting from the hasty trial to the dictator by retracing historical time through travels in the past (flashbacks) in the most diverse and unexpected ways. Nasta (236) reminds us how models of this experimental approach must be identified in the intellectual montage of Eisenstein and the revolutionary and polyphonic Citizen Kane by Welles. Between fiction and documentary, the public must learn to orient himself in the mountain of the film's disorienting, interlaced, spatio-temporally dispersed material. Thus, critics see in the director's choice to include in the film trailer the meeting between Ceaușescu and Kim Il Sung a perfect mise en abyme. Indeed, Ujică considers the North Korean dictator as the most complete example of a propaganda artist capable of synthesising Nazi aesthetics with the Stalinist cult of the personality (as Nasta reports it, from an exchange via mail with Ujică himself, 166). Although of two decades later, the Autobiography completes and precedes the documentation submitted in Videograms. Here, Ujică instead focuses on the gradual but inexorable rise of Ceaușescu; from his election to general secretary of 
the party, three days after the death of President Gheorghiu-Dej on March 22, 1965, to his imminent decisions to change the names of the Romanian Workers Party to the Communist Party of Romania (PCR) and the People's Republic of Romania to the Socialist Republic of Romania, until being elected president in 1974. The montage of official propaganda videos and TV archive footage shows the scale of the personality cult built around the Conducător. The big parades prepared to mark the country's Liberation Day, or Ceaușescu $60^{\text {th }}$ birthday, or to celebrate his title of Doctor Honoris Causa constantly exhibit gigantic official portraits of the Ceaușescu couple, as well as large tributes, flowers and gifts (Image 2). Significant space is then dedicated to international relations woven by the communist dictator, including De Gaulle, Richard Nixon, Mao, Tom Ford, Queen Elizabeth, Kim-Il Sung, Jaruzelski. On the other side, travels, rich markets, ceremonies, card games and volleyball matches, mountain hikes, popular parties and rock and roll, as well as an ambitious plan for renewal and urban expansion wanted by Ceaușescu. In an interesting analysis, Sorin Alexandrescu focuses on Ceaușescu's visits to an Alimentara and the Vitan bread factory, bringing both of them back to a fixed, studied in detail scheme of a dictator's " working visit» (11). Nevertheless, through an original and combined investigation of odd traces, unqualified speech acts (14) and multi-qualified visual acts (15), Alexandrescu comes to an eloquent interpretation that breaks the rigid codes of these visits. The existence of a dual register is revealed: not only there would be a contradiction between Ceaușescu's speech acts and both his facial expressions and gestures, but the absence of any interaction with the people, the forced silence and unnatural behaviours of the "simple folk "'s characters underline that the realism shown in these images is nothing but a pretended theatrical non-event, which is contrary to any documentary's principle. The film shows a stage where everything is prepared in advance and where people are obliged to follow the strict rules imposed by the dictatorship. Ujică's realism, far from being naive, can be seen as a meta-documentary: an intelligent deconstruction of the communist regime presented in the form of a self-destructive propaganda. Furthermore, the images chosen to represent the internal politics are always happy and positive, and there is no reason to suspect that this is an authoritarian regime, except for the summary trial sequences presented at the beginning. It is only after two hours (out of three, the total duration of the film) that the doubt about the illegittimate appropriation of power is installed: before a general assembly of the party, a lone opponent of Ceaușescu accuses him of evading a legitimate election by the members of the Congress, providing an unprecedented case in the history of the Romanian Communist Party. He is immediately booed, treated as crazy, and quickly judged as a minority protest by the leadership of the party. However, as the end approaches, after twenty-four years at the head of the party and fifteen years of presidency, the highest official of the state appears aged, tired and disputes are soon to break out. His speech on television defining popular protests exploded in Timișoara between 16 and 17 December 1989 as a result « of some groups 
of hooligans elements (hooliganiade) » is shown at this point. The invitation to the people to resist and marginalise those lonely escapades does not produce the indended effect. The Romanian people are eventually raising against twenty years of national-communism. Finally, as in a loop, Ujică returns to the images of the trial, which took place on 25 December, 1989 in a school of Târgoviște, fifty kilometres far from Bucharest. The Ceaușescu couple refuses to answer questions about, in particular, the infamous decision to open fire on the peaceful protesters in Timișoara and closes in arrogant silence while the charge of genocide is pronounced.

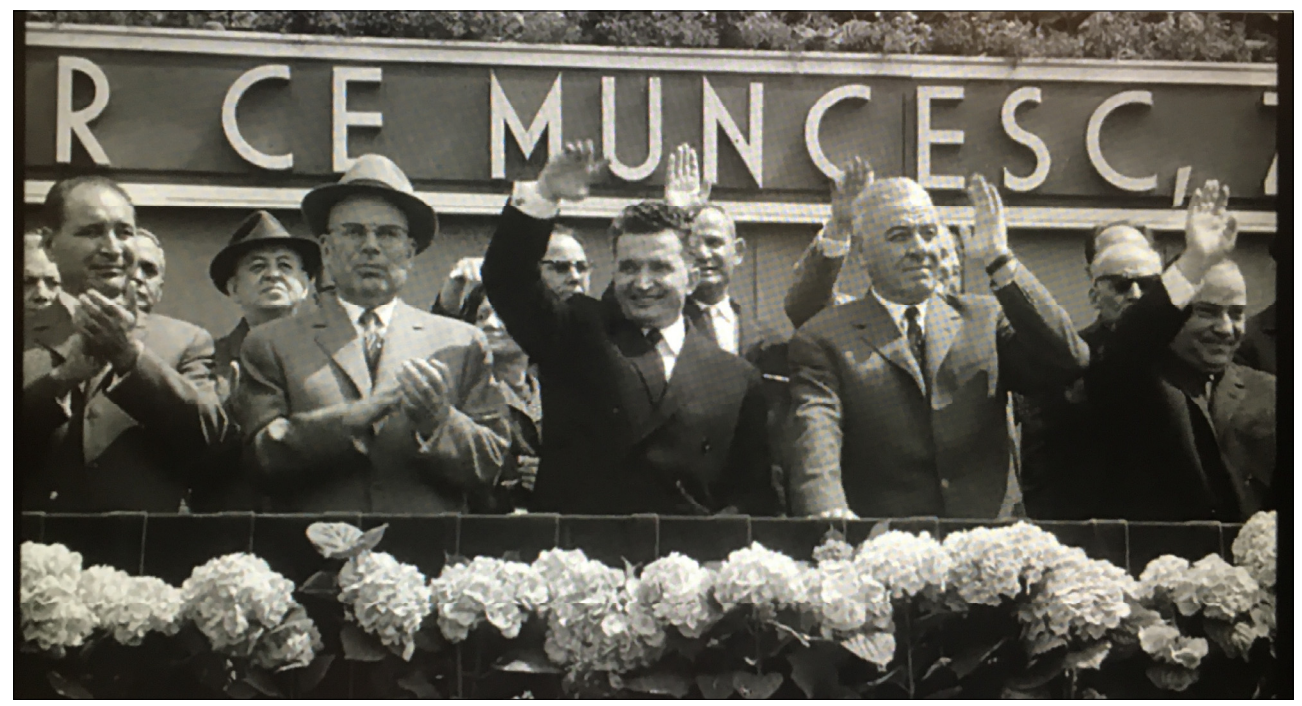

Image 2. Autobiography of Nicolae Ceaușescu

(Autobiography of Nicolae Ceaușescu, Andrei Ujică, Romania, 2010, min. 0:13:05)

Farocki and the German heritage

Born at the end of the war, in 1966 Farocki is a student of the first class of the Deutsche Film- und Fernsehakademie Berlin (DFFB), the German Academy of Film and Television based in West Berlin (www.dffb.de/html/en/akademie/alumni). From his earliest achievements, his main interests are already evident: political activism, the assumption of a critical philosophical posture and the desire to draw attention where official and traditional media channels are silent. His first job Inextinguishable fire (Nicht löschbares Feuer, Germany 1969) focuses on the production of napalm used in the Vietnam War. Here the young director explores the relationship between work, industry and death. Wanting to draw the viewer's attention to this chemical compound derived from naphthenic acid and palmitic one, whose horror was already known from World War II, Farocki avoids all emotional appeal. For this, he decides to show himself in the film, sitting at a table in an empty room, and speaking directly to the camera: « How to show napalm in action? How can we show you the inju- 
ries caused by napalm? If we show you images of napalm burns, you will close your eyes. You will close your eyes in front of the images; after, you will close them to the memory; and afterwards you will close your eyes to the facts. Then, you will close your eyes to the whole context. » Thus, he takes a cigarette and puts it on the back of his hand. On a still image, a voiceover explains that a cigarette burns at 500 degrees Celsius, while napalm burns at around 4,000 degrees Celsius. "When napalm burns, it's too late to extinguish it. You must fight napalm where it is produced: in factories. About thirty years later, in 1997 the American filmmaker Jill Godmilow (1943), realised in What Farocki Thought, a remake, in colour and English, of the film originally directed by Farocki in black and white and in German, and with which she won the International Rotterdam Film Festival. Godmilow's goal was to spread and make appreciable to the greatest number this important, early work of the German director.

Starting from this period Farocki begins to distance himself from the tradition of the German cinema of that time. Wenders, Fassbinder and Schlöndorff are accused of using too traditional cinematographic forms (especially in their editing and their use of canonical shot-reverse shots, (Didi-Huberman 73). Didi-Huberman refers to the experience of Hanns Zischler (1947), German actor and director, who perfectly summarised the approach that Farocki adopts from his early work: « a patient insistence on duration, an anti-kinetic look and materialist impulse determine the ethics and the aesthetics of his work » (in Didi-Huberman, 74). Antinhilist glance and materialistic passion, this is how Farocki intends to open the eyes of the spectators. Like when, in Inextinguishable fire, at the inability to show images of napalm, he decides to perform an action that apparently has nothing to remind us of napalm's military use against unarmed civilians. Yet, precisely in the action of extinguishing a cigarette on his arm, Farocki personally puts himself at stake in the act of denouncing, appealing to public accountability and awareness. Still Didi-Huberman suggests to compare the gesture of Farocki to that of Chris Burden who, in the performance Shoot, shortly after the release of Inextinguishable fire in 1971, is shot with a gun by a friend. But, as the French philosopher explains, the two gestures are not similar (Didi-Huberman 80). The difference lies in this, that Burden's act is conceived as an artistic performance and therefore has a precise aesthetic purpose. The American artist, who was then twenty-five years old, presents his gesture as a plastic work, a living minimalist sculpture. Farocki's burn, conversely, has no finality in itself, but represents a functional strategy to engage the spectator's awareness, the only possible gesture in the eyes of the director.

So, already from his first experiences it is possible to recognise a central theme that goes through all of Farocki's production, both audiovisual and written, which concerns, very precisely, the status of images. To begin with, Farocki's artistic and political militancy, as well as his historical subjects, are in permanent dialogue with Bertolt Brecht on one side and Walter Benjamin on the other. But we should not forget that during the decade running from 1974 to 1984, Farocki is editor of the journal Filmkritik. 
Didi-Huberman summarises very well this approach when he says that « a critique of the images can not go without a use, a practice, a production of critical images " (84). Yet, as Nicole Brenez reminds us, Farocki's critical posture is not limited to the written texts for his journal, but includes the choice of music, his editing and installations (Brenez 129). Indeed, his purpose is to criticise images and media that serve the interests of controlling society. Cinema, too, does not escape the history of the technologies of domination (Foucault), nor the dynamics of profit and the mass commodification, typical of the Kulturindustrie (the industralisation fo culture, Adorno). So, Brenez describes the work by Farocki as an immanent critique, in the sense that Schlegel uses writing on Goethe's Wilhelm Meister (Berlin, 1795-96) (Brenez 131). What characterises this work of Goethe is the fact that it contains its own criteria of artistic validity, while discussing and criticising them. Indeed, Farocki builds through his films a critical horizon through which he unmasks the ideological traits hidden under each historical event. In other words, it submits the images and events presented by the dominant narrative to a careful critical analysis. This is evident in the case of Inextinguishable fire (1969), but also to respect with another significant film of his critical approach, Images of the world and the inscription of war (Bilder der Welt und Inschrift of Krieges 1989). Twenty years after having treated, with a dry style and no sentimentalism, the disastrous impact of napalm on the human body, Farocki investigates this time the IG Farben company used by the Nazis for the manufacture of zyklon B, the gas exploited for the massacre of millions of Jews in the Auschwitz concentration camp. The images come from photographs taken by US bombers flying over Poland in 1944, but correctly interpreted only thirty-three years later by CIA agents. Once again, the director adopts a dialectical structure: photography is at the same time an artistic means and a testimony of genocide. Enlightenment, Aufklärung in German, represent European progress and is also a coded word in military language that translates as reconnaissance, but also an expression used by the police in the sense of the clarification of a case. The same images taken to direct bombardments are then used to identify unexploded mines and allow the reconstruction. The photograph of a woman is shown shortly after. The voice-over that accompanies the story of the film assumes that she was immortalised at the time of the examination of prisoners at the entrance of the camp, perhaps by the same SS who is responsible for her death. On another black and white photographic document, a girl smiles; it is part of a group of women prisoners in Auschwitz whose head has been shaven. It is impossible not to mention here the Section VII of the Theses on the Philosophy of History by Walter Benjamin (which is also the final text of the German philosopher, written in Paris in 1940 and published posthumously in 1942 by the Institute of Social Research in Los Angeles): « There is no cultural document that is not simultaneously a document of barbarism ». Culture and progress can come from the most contemptible social violence. Yet Harun Farocki is not limited to denounciation, but he is also able to transform the critical use of reason and the camera in an authentic visual activism (Brenez 
137). As in Inextinguishable fire, the activity of thinking and filming is transformed into concrete action, stage performance, demonstration. Nevertheless, Farocki's artistic gestures never yield to voyeurism, exhibitionism, or excessive exposure. Farocki intends to show without showing, to raise critical consciousness without falling into sentimentalism, to present an event together with its absence. And to do this, he uses the documentary form, but through a unique collage of different sources of images. It is the case of Videograms a revolution (Videogramme einer Revolution, Germany, 1992), which the Argentine filmmaker Mauro Andrizzi, author of Iraqi Short Films (2008) and En el futuro (prize Queer Lion at the 67th Venice Film Festival, 2010) defines as the most subversive film in cinema history. For him, Videograms is nothing short than " how to make revolution with television ", and describes as follows what he considers the best scene of the film: «Ceaușescu's face captured by the official TV channel when the people invaded the Bucharest central Committee. No reverse shot into the crowd, just his frozen face, staring into space. Then the camera is pointed to the sky, and there is no more than sky and cries. Pure cinema. The revolution live » (Cahiers du Cinema 62).

\section{Videograms of a revolution}

\section{(H. Farocki, A. Ujică, Germany, 1992, 107 ', 16mm)}

The film, which covers in one hour and forty-seven minutes the five days from 20 to 25 December 1989, which passed between the manifestations in Timișoara and the execution of the Ceaușescu couple, begins and ends in the same way: with two poignant testimonies of Romanian citizens deeply affected by the events of December 1989. At the beginning, we are disoriented by the cries of pain of an injured young woman lying in a hospital bed. Although she suffers, she declares her willingness to address the camera with a short message. Her name is Marcau Rodica, she is part of the Coop of Timișoara and has been shot by troops of the Securitate in returning home after having defended a store. She denounces 4,000 deaths as well as countless arrests and all sorts of violence and torture carried out against her comrades. On 20 December, the popular uprising against the communist regime of Ceaușescu which lasted four days proclaims Timișoara first free city in Romania, following which the Romanian Democratic Front is founded. The words of this girl sordidly hit by the repressive systems of the regime sound like a brave wish for all the duration of the film: «We want a better life, that everyone is happy, that there is no more dictatorship anymore and that Ceaușescu is sentenced here, in Banat ». The rest of the film is organised into twenty-six episodes, each of them opened by a black frame and a title in large white letters. From the first of these sequences, a voice comments the images which appear on the screen, mostly amateur footage or images from the archives of the regime's official television channel (Televiziunea Română TVR), later renamed Free Romanian Television (Televiziunea Română Liberă, TVRL), but also censored material and footage from foreign televisions like the English Independent Television News, 
TV Novi Sad and France Regions 3. First, in order to help the viewer to orientate himself on the screen, a spatiotemporal contextualisation and images' sources are given. On December 20, 1989 around noon an amateur camera films from the window of a university campus in Timișoara demonstrators who are heading downtown. The voiceover describes very precisely the images that are shown: they are clearly separated, unevenly, into two parts. The first plan, much larger, is occupied by uninteresting buildings, while in the background the action takes place.

The second sequence is titled: «21.12.1989, Bucharest». The day after the events of Timișoara, Ceaușescu's speech is carried live by TVR. The scene is carefully prepared, the official portraits of the couple are displayed with communist slogans, the square in front of the Central Committee of the party is swarming with people. Everything is primed for an ordinary gathering under the control of the government. But suddenly the look of the Conducător is captured by something, we hear screams and crowd movements. One of Ceaușescu's advisers goes out on the balcony to tell him: «They enter the building ». We still hear a voice asking, more surprised than scared, if it is an earthquake, when the transmission is abruptly interrupted. A red frame now occupies the screen. The next sequence is titled « Live for the last time » and shows the

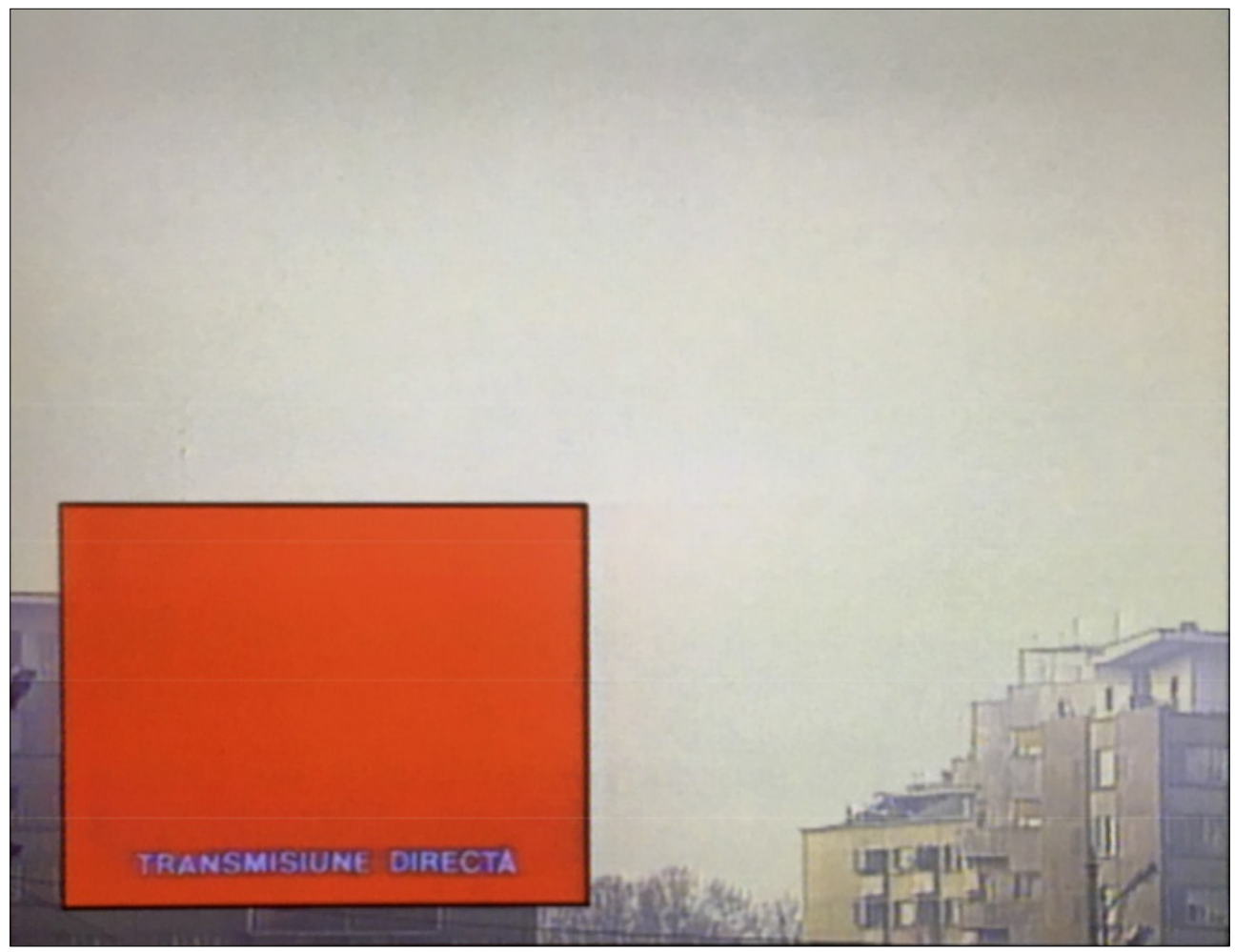

Image 3. Videograms of a revolution

(H. Farocki, A. Ujică, Germany, 1992, min. 08:40) 
images that the cameras of the regime continue to record. Ceauşescu, as the voiceover suggests, urges to keep calm. His voice sounds like a disturbed phone. Indeed, the ability of the filmmakers here is to emphasise unimportant details which, in this particular context, assume an ironic, subversive connotation. Ceaușescu repeatedly pronounces the words " Halo halo », as if the communication had been actually disrupted. We also hear Elena Ceaușescu taking the floor several times, always with her very authoritarian and arrogant manners. The cameramen were obliged to film the sky if an unanticipated event occurred and thus the television show promptly recommences, silently, and on our screen the actual live images are shown alongside those in small, shown by TVR.

Then the voice calmly resumes the events dynamics, this time showing pictures recorded by an official camera which, driven by curiosity but with some discretion begins filming the central square. Firstly, we see the beginning of the speech, to which the crowd participates in a very orderly way. Next, a stirring movement breaks out, probably due to a growing irritation towards the rigid rules imposed by the dictatorship. As Dietrich Leder reports it, " abandoning the standard choreography reveals the people's unwillingness to continue to accept the regime » (Leder 90). People crowded outside the entrance of the Central Committee. In the following frame the order is restored, the insurgents reach again the place that has been assigned to them and Ceaușescu resumes his speech. Finally, another prospective is given. In the amateur video, a citizen in his apartment in Bucharest first records the speech transmitted on television and after directs his camera toward the street, where people have come down and are moving towards the central square. "A camera probes the situation ». The same man then places his camera on the rooftop of a building in the University square: people shout « Free elections! ». It's interesting to see and analyse the slogans that arise spontaneously during a revolution and which are shown here thanks to these exceptional and rare documents recorded during the days just before the fall of Ceaușescu. We have collected those emerging more often from the four days of mid-December 1989, registered by amateur and unpublished videos gathered by Farocki and Ujică. Freedom ! Truth! We stay ! Cease fire! Each slogan is often initiated by one person and then taken up by all the others, finally we can hear a single and unanimous choir. They are many times accompanied by gestures: the closed fist lifted skyward, index and middle fingers raised in the sign of victory. This is now the night of 21 December and the University walls are covered with candles. Again a common cry emerges: Timișoara! And then: Down with Ceaușescu! When an army tank is stormed and burned.

«22.12.1989, Bucharest ». The TVR-Acutalități announces the treason and suicide of Defence Minister Vasile Milea. Far from being confirmed, the circumstances of this event remain uncertain today. In January 1990 Libération (reported by Repubblica on 11.01.1990) publishes information from Western intelligence agencies that give Milea dead on December 19, following his refusal to send reinforcements after the massacre 
perpetrated in Timișoara on December 17. According to the Romanian press in fact, after the events in Timișoara, Nicolae Ceaușescu accused the Defence Minister Milea and General Vlad (who later became minister in his place) of betrayal for not having distributed ammunition to the soldiers who should have fired on the crowd. Yet, Vlad remains loyal to Ceaușescu and Defence Minister Milea, head of the Securitate, is summoned by Elena in his cabinet. In truth, she was preparing an attack and according to these same sources Milea was assassinated in the antechamber of the Cabinet by Deputy Prime Minister Ion Dincă. "Crossed paths ». The morning of that same day, December 22, in downtown Bucharest another amateur camera films the confrontation between protesters and security forces. The images mark the date and time: 11:13. Hence, soldiers from the Securitate with their white shields fled. The voiceover explains that we are right between the place of the Central Committee and the headquarters of the television: the two key places of the regime that will then become symbols of the revolution. Meanwhile, "At the Central Committee » people are celebrating their entry by throwing papers and books of the party off that same balcony where the day before the dictator had given what will prove to be his last public speech. The element that arouses interest here is represented by the way in which these images are taken. The voiceover explains that this is a professional camera appointed for recording Ceaușescu's public appearances. And this is the same camera that the day before surreptitiously recorded « more by curiosity than by choice » images of the interruption of the official discourse. Then « the cameras go down to the streets ». The same person who was filming from the top of the committee palace, is now down in the square where it is possible to see the dictator and his wife escaping on a helicopter. An image magnification allows to identify Nicolae and Elena Ceaușescu. There are now «more and more cameras ». While the tyrant and his wife are escaping, the recordings are multiplying to witness the first " live " revolution in history. "To the television ». Giorgio Agamben, as reported by Benjamin Young in Means without purpose: notes on politics wrote: "In the same way when we said that after Auschwitz it is impossible to write and think like before, after Timissoara, it won't be possible to watch TV the same way anymore " (Young 245). Indeed, the television medium plays a central role in the Communist propaganda both during Ceaușescu's regime, where it helps strengthen and develop the cult linked to the personality of the dictator, and, especially, during the revolution. The central and main part of the film, which comprises the ten sequences ranging from the ninth to the nineteenth, concerns the role of television. Videograms of a revolution addresses specifically the issues of the use and abuse of images in politics, and the link between television, violence and democracy (Young 245). According to Farocki, images are a common good and his work represents the attempt « by interposed montages, to "abolish and [to] erase separations in order to teach [us] to make a new use of them, to play with them » (Didi-Huberman 166). And again Didi-Huberman, this time quoting Benjamin, adds: « to organise pessimism means nothing else [that] discover in po- 
litical action a space hundred percent held by the image » (170). Farocki himself describes with the following words the genesis of the film: «In 1990 I read a book about the fall of Ceaușescu, edited by Hubertus von Amelunxen and Andrei Ujică. I had the idea for a film in which a handful of people who understand something about politics and images would have analysed in details a series of images of that December 1989 » (Farocki, 2009, 228). Ujică then suggests Farocki to direct the film together and both head to Bucharest during the summer 1991. Farocki gives an accurate description of his first impressions. "In the countryside of Romania we felt like we were back in the nineteenth century. Two horses were pulling a harvest carriage, the carter was asleep » (Farocki, 2009, 228). Farocki and Ujică then begin their documentary archival researches to identify the greatest number of images shot during the fall of the regime. But after watching several hours of footage, they realise that this is not a «television revolution » because the images show tens and hundreds of thousands of people undoubtedly taking part in the overthrow of the communist dictatorship. During the summer of 1991, they begin the editing, but at the end, in order to correctly date the documents in strict chronological order, they return back to Bucharest in the fall of 1991. In total, they have done five months of research, nine months of editing and three months of post-production. Farocki comments ironically, «nobody had suspected such a rapid and non-violent collapse of the Soviet Union and the Eastern bloc » (Farocki, 2009, 228). The film, however, remains very vague in this long central part, the one where the voice off disappears and the cameras focus around the television's headquarters, besieged from different sides and eventually occupied by the revolutionaries. Finally, the television is driven on the central square but this time instead of filming in a privileged position from above, the camera passes through the crowd until the feet of the balcony of the former central committee. Yet at present the versions of the 1989 Romanian revolution differ. The official one favours a spontaneous revolution brought about by Romanian people firstly in Timișoara, and then in Bucharest, but there are several facts, however, whose interpretation remains doubtful, from the 60,000 exposed corpses which were presented as the dead of Timişoara but were in fact exhumed for the occasion from a mass grave. Or the relative speed with which the army turns its back on the Conducător to switch to the other side of the revolution. Until the identification of those famous " terrorists " that the days after the country's liberation shoot over the opponents. In one of the texts of Farocki collected by Christa Blümlinger in the volume Recognise and pursue entitled I do not recognise myself in Bucharest, the German wrote: "Who is the enemy, what strengths he disposes of, where is he. We designate the enemy by "them", "these lunatics", "foreigners", "two of these rats," "reserve troops which I never knew they existed," "underground regiments", "these criminals" and "terrorists" » (Farocki 59). These are the same terrorists who, within hours from the flight of Ceaușescu, seem to attack first the television headquarters, then the headquarters of the telephone company. The situation seems to degenerate when the conflict is moving into the streets. The images record entire neighbourhoods of Bucharest besieged. 
But «where the shots come from? ». From the twentieth sequence, the voice off resumed, it's the beginning of the third (and last) part of the film. Images show this time Victory Square in Bucharest on December 23, 1989, where Ceaușescu had made to build new buildings, never accomplished. It's here, in these empty buildings, that the « enemy » is believed to be hiding. Both versions are presented here: it could be some elements of the Securitate who remained loyal to the tyrant or it could be a strategy put into action by the secret services (domestic and abroad, in line with the party dissidents) to give the army a decisive role in the revolution. What surprises most an English reporter who is speaking while being directly under fire is that the battle lasted over twenty-four hours and that, despite the inferiority of number and ammunition, nothing could dislodge the snipers. Nevertheless, the voiceover adds that the act of belief in the constant presence of the enemy is due to a habit, in memory of the fear that the regime has been established for years as a necessary condition for the preservation of the power.

«24.12.1989, Bucharest ». The terrorists («Lebanese and Syrians we parachuted») are folded into the woods for lack of ammunition. Libertate! Death to the tyrant! Ceaușescu will not live New Year's Eve! «Identification »: the employees close to the regime escaping and often with false documents, are caught and unmasked.

«25.12.1989, Bucharest». Many cameras are gathered in a room, everyone fixes the screen waiting for images that only one camera was able to film. This is the real political role of the image, to record history. However, as never before the 1989 revolution, the images were not limited to record events, they - whether they come from professional, official, hidden or even amateur cameras - have made history. We can say that with Videograms a revolution, images, the absolute protagonists of the story, overcome their nature of recording evidences to become the very condition of the development of events themselves. Clearly, December 1989 could not have ended the way it did without the presence of images. And although they may be hidden, destroyed and obscured, their ambiguous and dialectical power, remains unstoppable. In its original function, the medium of the camera makes the history visible, it manifests the events. But during the Romanian Winter '89, the media have become the ontological condition of the history, images have made the revolution. "If the film is possible, then the history is also possible ». In " release ", the Free Romanian Television (TVRL), proudly displaying the new flag of Romania finally liberated from the terrible communist emblem (Image 4), announces that: « The $25^{\text {th }}$ of December, 1989 was held the trial against Nicolae Ceaușescu and Elena Ceaușescu before a special military court. The charges were: 1 . genocide, more than 60,000 victims; 2 . deterioration of national power through armed actions against the people and the state; 3 . destruction of public property by demolition and damage to buildings by explosion in cities, etc.; 4 . deterioration of the national economy; 5 . attempt to escape from the territory with more than a billion dollars deposited in foreign accounts. Because of these serious crimes against the Romanian people and Romania defendants Nicolae and Elena Ceaușescu 
were sentenced to death and to the confiscation of their property. The judgment is defined, the sentence has been executed. The film of the events will be broadcasted during the evening ».

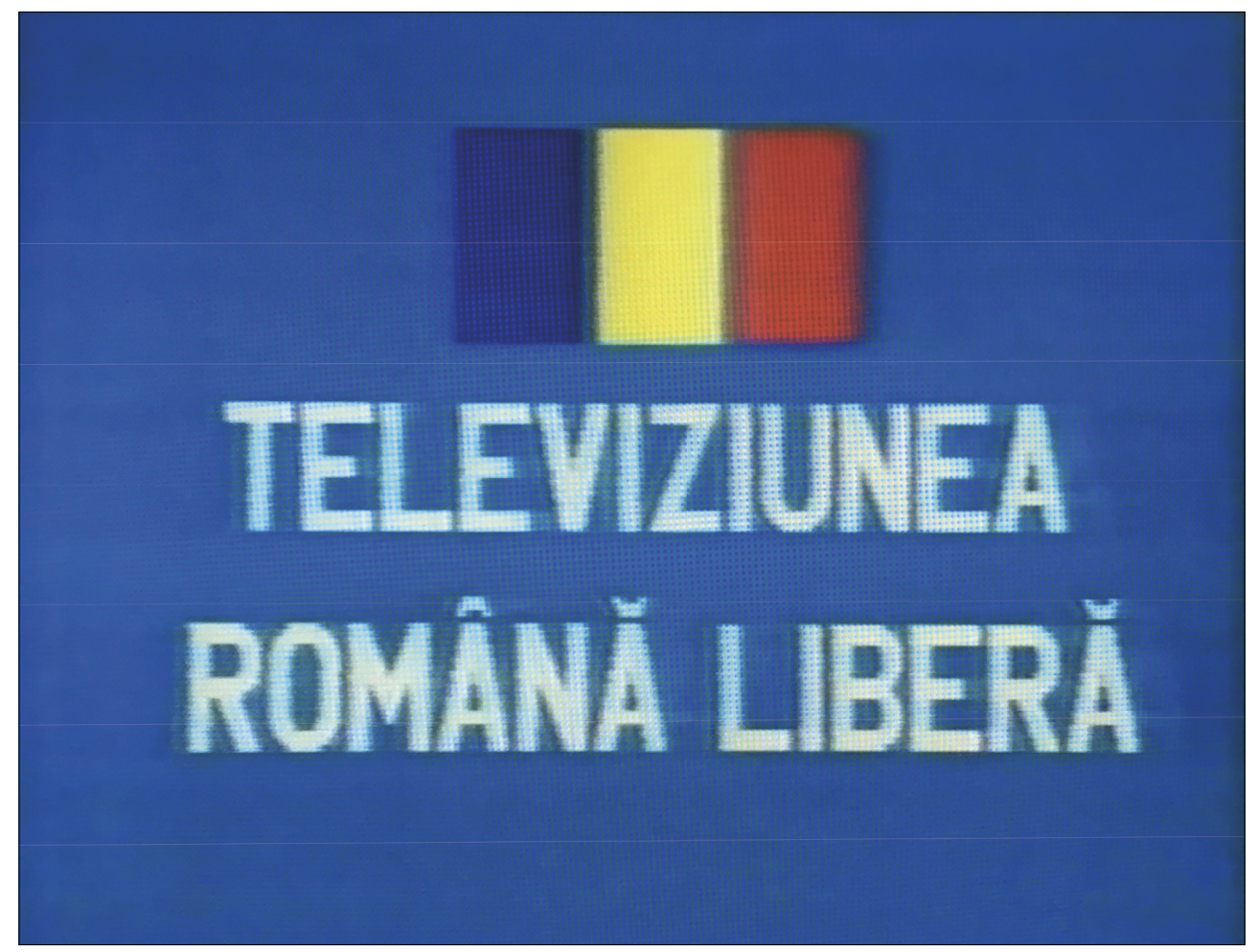

Image 4. Videograms of a revolution

(H. Farocki, A. Ujică, Germany, 1992, min. 1:37:04)

«The last camera » shows the capture of the Ceaușescu couple, the medical examination which the accused are subject to late check their good condition and part of the trial which sees them convicted of genocide and crimes against the Romanian people. Finally, the bodies are displayed on the screen, and the camera turns off.

In the end, Farocki and Ujică offer a circular conclusion with the speech of a man inside a factory, among his colleagues. After recalling the abuses perpetrated by the Ceaușescu regime and the restrictions of personal freedom that Romanians have had to endure for more than fifteen years, his voice breaks in tribute to the sons who have sacrificed themselves for the cause of the revolution and to the children who have lost their parents. Communist dictatorship has introduced the envy of the other, the fear of the stranger, divisions between peoples and hatred towards minorities. Yet « the Germans, the Hungarians were our friends » and his message is nothing but full of hope. Finally, those wishes by Rodica could have been realised, thus, in tears, « Happy Holidays Romania and live free! ». 


\section{Works Cited:}

1. Alexandrescu, Sorin. "Autobiografia lui Nicolae Ceaușescu, by Andrei Ujică. What kind of realism ?". Close Up: Film and Media Studies, vol. 1, no. 2, 2013, pp. 5-22.

2. Brenez, Nicole. "Harun Farocki and the romantic genesis of the principle of visual critique." A. Ehmann, Eshun, K. (ed.). Harun Farocki: Against what? Against whom?. London: Koenig Books, 2009, pp. 128-142.

3. Brenez, Nicole. "Images activistes: florilège intempestif de films subversifs." Cahiers du Cinema, no. 647, July-August 2009, pp. 61-62.

4. Didi-Huberman, Georges. Remontages du temps subi: l'œil de l'histoire, 2. Paris: Les Éditions de Minuit, 2010.

5. Farocki, Harun. "Written trailers". Translated from German by Antje Ehmann and Michael Turnbull. A. Ehmann, Eshun, K. (ed.). Harun Farocki: Against what? Against whom?. London: Koenig Books, 2009, pp. 228-229.

6. Farocki, Harun. Reconnaitre et poursuivre. Dijon: Théâtre Typographique, 2002.

7. Gras, Pierre. Good Bye Fassbinder!. Arles: Editions Jacqueline Chambon, 2011.

8. Young, Benjamin . "On media and democratic politics: Videograms of a revolution." Elsaesser T. (ed.). Harun Farocki: working on the sight-lines. Amsterdam: Amsterdam University Press, 2004, pp. 245-260.

9. Leder, Dietrich. "Vidéograms of a revolution (Videogramme einer Revolution)." Reichenbach B. (ed.). Harun Farocki: diagrams. Images from ten films. Köln: W. König, 2014, pp. 90-116.

10. Nasta, Dominique. Contemporary Romanian Cinema: the history of an unexpected miracle. London, New York: Wallflower Press, 2013.

11. Seung-hoon, J. and Szaniawski, Jeremi (ed.). The global auteur: the politics of authorship in 21st century cinema. New York: Bloomsbury Academic, 2016.

12. Uricaru, Ioana. "Follow the money: financing contemporary cinema in Romania". Imre A. (ed.). A companion to Eastern European Cinemas. Malden (Mass.): Wiley-Blackwell, 2012, pp. 427-452.

\section{Online}

13. http://ricerca.repubblica.it/repubblica/archivio/repubblica/1990/01/11/esercito-romeno-preparava-un-golpe-per.html.

14. The German Academy of Film and Television in Berlin. 